\title{
Ethnic Reasoning and the Making of the Nation of Botswana
}

\section{Malebogo Kgalemang \\ ORCID iD: https://orcid.org/0000-0003-4373-7611}

\begin{abstract}
This article explores the making of the nation of Botswana. It analyses how Botswana imagined and narrated itself as a nation. It theorises the making of Botswana through Denise Kimber Buell's concept of Ethnic Reasoning, a discourse a community utilises to create a collective identity that distinguishes it from other communities. This article discuses Botswana's Ethnic Reasoning through the following questions: who and what is a Motswana? What modes of narratives, rather stories of representation, were used to narrate Botswana? What means of construction and persuasion did the nation of Botswana imagine and use? What categories created the nation of Botswana? It argues that the nation of Botswana uses the categories of race, ethnicity, the tribes, and language, to construct Batswana. It concludes that Botswana's Ethnic Reasoning has remained fairly consistent from its inception to the present. It foregrounds also that through Ethnic Reasoning, Botswana was able to create an ideology of the universal Motswana citizen through an appropriation of a particular ethnic Motswana people.
\end{abstract}

Keywords: Ethnic Reasoning, the Nation, Race, Ethnicity, the Tribes, and Language.

\section{Introduction}

Nestled deep at the centre of Southern Africa is the country of Botswana. A nation that considers itself unique and prides itself on sound and good democratic principles and practices. A nation that makes claims of an excellent economic system and celebrates itself for a peaceful existence exemplified by lack of a civil war. This is Botswana and its exceptionalism. Its anthem song, 
written and sung in the national language, Setswana, evokes Botswana's sense of unity. The anthem's first stanza is reproduced below:

Fatshe leno la rona

Ke mpho ya Modimo

Ke boswa jwa borraetsho

A re nneng ka kagiso

The English translation is thus:

This land of ours

Is a gift from God

It is an inheritance from our forefathers

May it always be at peace

Botswana's anthem is a religious and patriarchal construct instrumental to its national narration and creation. In his book, Imagined Communities (c2006), Anderson weaves an 'anthropological spirit' (2006:6) definition of a nation. Anderson relays that the nation is 'primarily an idea' (2006:6) and an 'imagined political community' that is 'both inherently limited and sovereign' (2006:6). The noun 'imagination' is key to understanding a nation's aspirations, and self-understanding. Anderson (2006) argues that it is important for a nation to imagine itself because members of the nation are foreigners to each other. Members of the nation, Anderson argues that they 'will never know most of their fellow members, meet them, or even hear of them, yet in the minds of each lies the image of their communion' (2006:6f). Central to this, according to John McLeod, is that 'the idea of the nation are notions of collectivity and belonging, a mutual sense of community that a group of individuals imagines it shares' (2006:69). Therefore, Imagination is crucial to a nation's unity and nationhood. Dipesh Chakrabarty emphasises 'imagination' to the 'analysis of nationalism' (2000:174f). However, he cautions that the 'category imagination' (2000:174) 'remains a mentalist, subject category in Anderson's thought' (2000:175). Therefore, imagination, according to Chakrabarty embodies a 'subject-centred and a subject practice. It is in that sense, an inherently heterogeneous category ...' (2000:175).

However, nationalism has its own hidden agendas. In its path towards national unity, it utilises historically existing nativist categories to create and 


\section{Malebogo Kgalemang}

narrate the nation. Anne McClintock asserts that nationalism 'inhabits the realm of fetishism' (1993:70). This fetishism, according to McClintock (1993), are forms, practices, or even categories through which the nation is articulated. The general logic of fetishism is representation strategy. McClintock asserts that "nationalism takes shape through the visible, ritual organisation of fetish objects (flags, uniforms, airplane logos, maps, anthems, national flowers, national cuisines, and national architectures) as well as through the organisation of collective fetish spectacle (in team posts, military displays, mass rallies, the myriad forms of popular culture, and so-on)' (1993:71, some of which are found in Botswana's nationalism like Botswana's flag. These categories include but are not limited to race, flags, tribes, ethnicity, and language. The appropriation of these categories does not depart from innocent, imagined, or holy terrains and spaces. They often depart from imagined spaces and practices that work through the binaries of exclusion and inclusion, centre and periphery, and superior and inferior. They have a rhetorical function that begs for critical reading. This, therefore, demands a critical reading of their production.

This article is an exploration and discussion of the nation of Botswana. My intention is to explore Botswana's imagination and narrative in the making of the nation. I seek to problematize the making of the Botswana nation by scrutinising and analysing the aforementioned categories I suggest were important to the country's nation building and making. The methodology to this article is desk top research study. It depends wholly on secondary literature through a use of a number of sources. These sources were designed principally as descriptive study to provide date for information and analysis.

My exploration of the making of the nation of Botswana draws from Denise Kimber Buell's theoretical concept, Ethnic Reasoning, detailed in her book, Why This New Race: Ethnic Reasoning in Early Christianity (2005). Buell coined Ethnic Reasoning to signify a set of discursive strategies whereby a group or people or a community render their own collective identity in terms of a peoplehood. Although Buell's work is situated contextually in the history of the formation of early Christianity, her theory and insights are useful and relevant to this work's goal. Buell's overall theory provides a framework through which this work scrutinises.

In Ethic Reasoning (2005), Buell attends to the ways Ethnic Reasoning was developed. Ethnic Reasoning 'culturally uses available understanding of human difference, which we can analyse in terms of our modern concepts of 'ethnicity', 'race' and religion' (2005:2). She argues that a new formed group 
of people 'mapped themselves into the ethnic, racial and religious terrain' (2005) of their contexts' discourses of identity, and identifies the categories 'ethnicity' and 'race' as discursive strategies instrumental to mapping a peoplehood. Discursive strategies (Buell 2005) work rhetorically. They often are steeped in modes of persuasion and ideas about a peoplehood. Buell indicates that Ethnic Reasoning is not an alien rhetorical strategy but is appropriated from within its contexts of existence (2005). These rhetorical situations, argues Buell, are 'even more important than the presence of specific terms' (2005:2). She proposes that ethnos (ethnicity) and genos (race) are central, if not foundational categories, to Ethnic Reasoning. However, she takes an anachronistic approach to the categories of ethnicity and race by refusing to define the terms simultaneously, insisting on their interaction and intersection. My argument is that Ethnic Reasoning through the strategic utilisation of race, tribe, ethnicity, and language, embody the very forms of nationalist definitions, articulations, and comprehension, in the making of the nation of Botswana.

I pursue the making of the Botswana nation through the following questions: how did the categories of race, tribe (and or ethnicity) and language, function strategically in the making of the nation of Botswana? What work, rhetorically, do the discursive strategies of race, tribe, and language achieve? How did Botswana use the same categories to envision, narrate, and construct itself? In the construction of the Botswana nation, what was excluded and included? Perhaps these are broad, overarching, and complex questions, and this article may not answer all of them fully. However, I pursue these questions because of a drive to comprehend the conceptualisation and the production of meaning of the Botswana nation.

Ethnic Reasoning provides a lens through which we can write a nation's self-definition. It provides a frame through which nation and social identity development are instrumental to the making of a nation and its nationalism. Ernest Gellner argues that 'Nationalism is not the awakening of nations to self-consciousness: nationalism invents nations where they do not exist' (2005:6) because as narratives, they 'have to be made; they are not simply given by God, history or ethnic group' (2005:5).

To pursue the above, I examine and scrutinise the making of the Botswana nation through the following structure: 
- Botswana: Initial Postcolonial Formations

- Ethnic Reasoning and The Politics of Race

- Ethnic Reasoning and The Tribes

- The Making of the Nation through Ethno-Language

- Epilogue

'Nations themselves are narrations,' asserts Edward Said in his book Culture and Imperialism (1994: xiii). Partly following Homi Bhabha, this work traces the narrative of the Botswana nation, as a 'powerful historical and postcolonial idea' (1990:1). In the introduction to Nation and Narration (1990), Bhabha articulates the following:

Nations, like narratives, lose their origins in the myths of time and only fully realize their horizons in the mind's eye. Such an image of the nation - or narration - might seem impossibly romantic and excessively metaphorical, but it is from those traditions of political thought and literary language that the nation emerges as a powerful historical idea in the west (1990:1).

Bhabha compares nations to narratives and emphasises that the narration is also an important feature of the nation (1990). Nations, Bhabha notes, are realised through the mind's eye, transformed into literary language to be visualised and understood (1990). Narrating the nation is a form in which nations create myths, stories, practices, and forms about their own existence and legitimisation.

In the Oxford's very short introduction to Nationalism, Steven Grosby defines the nation thus:

The nation is a territorial community of nativity. One is born into a nation. The significance attributed to this biological fact of birth into the historically evolving, territorial structure of the cultural community of a nation is why the nation is one among a number of forms of kinship. It differs from other forms of kinship such as the family because of the centrality of territory. It differs from other territorial societies such as tribe, city-state, or various 'ethnic groups' not merely by the greater extent of its territory, but also because of its relatively uniform culture that provides stability, that is, continuation over time (2005:7). 
Grosby describes the nation as a 'territorial community...territorial structure of the cultural community' (2005:7). He gives it a biological origin which culminates into its kinship. However, the nation is different from other types of kinship because 'it's relatively uniform culture provides stability' (2005:7). Most importantly is the native identity of nationalism cemented by Grosby (2005). The native identity can be essentialised to tribes and or ethnicities,particularly tribes, in the context of Botswana.

\section{Botswana: Initial Postcolonial Formations}

The nation is not only a Western idea. It is also a postcolonial idea and project. Thomas Hodgkin asserts that for many African countries, nationalism was perceived as the 'road to freedom and to progress not only because it leads to the end of the imperialist rule, but also and above all reorganisation of colonial societies. Nationalism, if you like, is a mode of birth not the modern world' (1957:71). Botswana, like any African nation is a postcolonial idea because it is weaved with the history of colonial and imperialism protectorate. A postcolonial nation is one that emerges from colonialism and begins a purposeful journey of rebuilding itself after the history of colonialism.

Issa Shivji asserts that the central constituent of 'nationalism was and is anti-imperialism' (2003:3). Shivji asserts that African nationalism's agenda was 'a demand and struggle against, rather than for, something. It was an expression of a struggle against denial - denial of humanity, denial of respect and dignity, denial of the Africanness of the African' (2003:3). Simply put, it was a nationalism for decolonization. Shivji asserts that nationalism for decolonization is a 're-Africanization of minds' (2003:3). Nations, therefore, seek to 'rebecome Africans' (2003:3).

Nationalism, notes Shivji (2003), precedes Nations. Ironically, Shivji does not define Nationalism. The creation and construction of the nation culminates with its liberation from the empire. During that particular historical moment, nations that had been colonised began to make demands for their own sovereignty and liberation, and constructed themselves along. Botswana is imagined and constructed from a postcolonial space. Therefore, Nationalism is a postcolonial project that it is inherently nativist.

Shivji proposes three aspects of African Nationalisms. They are 'PanAfricanism, Independence or Freedom, and (Racial) Equality' (2003:6). He observes that each is premised on 'opposition to imperial domination' 


\section{Malebogo Kgalemang}

(2003:6). Moreover, he writes that the struggle in defining each 'differs across historical periods' (2003:6) and it is not so much a 'nation in search of, or struggling for, identity, dignity, and independence, but rather a people imbued with a common experience of domination and exploitation asserting their 'claim-in-struggle' (2003:7). Furthermore, African Nationalism can be characterised by three elements, which are: Unity, Independence, and Equality. These elements, according to Shivji, are intersecting and inseparable (2003).

The nation of Botswana begins disparately and remotely with the Batswana tribes of a 'lineage clusters of separatist chiefdoms' (Mogalakwe 2006:71). These tribes claimed equal statuses but 'remained weak militarily and suffered military aggression from the Boers' (2006:72). In 1885, Britain, though having been unwilling to offer the Batswana protection against the Boers, sent Sir Charles Warren to declare a British Protectorate. He was to inform the three key Batswana kings about the British Empire's intention. Khama and all agreed except Sebele who resisted him in April 1885, but Khama agreed to the protection in May 1885. Therefore, on 30 September 1885, Bechuanaland British protectorate was founded.

Almost ten years later, 1894 to be precise, the imperialist Cecil John Rhodes had desired to annex Botswana to his agenda and eponymous, Rhodesia colonies. With a goal to construct a railway line from Cape to Cairo, Rhodes made a formal request. (Mogalakwe 2006:73). His request was met with opposition from the Batswana kings that in 1895 three male chiefs, Khama III, Bathoen I, and Sechele I, accompanied by the missionary Reverend Willoughby, travelled to England, the belly of the British Empire. According to Neil Parsons, the three did not only meet Chamberlain but also met with Queen Victoria, and their visit was also a huge 'triumphal success in public relations' (1971:41). They toured Wales and Scotland, which became highly effective and succeeded in convincing the 'powerful sectors of the British electorate into supporting them and putting pressure on the British government for a favourable political settlement' (1971:41). Parsons writes that ultimately the British Empire acceded to their request to block the annexation of Botswana to Rhodesian colonies. Bechuanaland Protectorate continued to be ruled by Britain and the reign of the Batswana kings continued their rulership (1971:141).

I propose that the three male Dikgosi's sojourn to British/ Bechuanaland Protectorate sowed the seeds of the nation of Botswana. The seeds continued to germinate under the colonial administrators and the Dikgosi until the Bechuanaland protectorate gave way to the Republic of Botswana in 
1966 and it began the process and practice of self-governance. The dawn of Botswana's independence was also the development of a nation Botswana. Independence is a practice of nationalism. The independence would inevitably enable Botswana and its founders to begin the process of creating a peoplehood through Ethnic Reasoning. Moreover, Botswana's nationalism renders, borrowing from Laura Charisma, 'precolonial cultural traditions in order to sanction or define (its) nationalist project' (2004:187). A nation defines, according to John McLeod, 'notions of collectively and belonging, a mutual sense of community that a group of individuals imagined it shares' (2000:69).

This section has provided the initial postcolonial conceptualisation of Botswana under Bechuanaland. Below, I explore the various forms of nationalist narrations through Ethnic Reasoning. I seek to show the salient features of Botswana's nationalist Ethnic Reasoning through the following categories: race, ethnicity, and language.

\section{Ethnic Reasoning and the Politics of Race}

Buell asserts that Ethnic Reasoning allows groups of people to 'not only describe themselves as a people but also to depict process of becoming' (2005:139). A group of people utilise Ethnic Reasoning to become either a nation or a religious group. Ethnic Reasoning enables a group or nation to create a collective identity. It provides a lens through which people will perceive themselves as one and united. Collective Identity works through shared values attached and commonly held by a group of people. It is a process of how individual members of a social political group strategically formulate meanings, discourses and ideals to form a collective unit.

This section examines how Ethnic Reasoning through race was used to create the nation of Botswana. It concentrates on the construction of race in Botswana during the protectorate and pre-independence, and how the history of race is written into post-independence Botswana. Three examples of race and racial political constructions and tensions are discussed. They are Batswana, Asians, and historical contact zones with white people; the marriage of Seretse Khama to an English white woman, Ruth Williams, and lastly, the codification of race in the national flag of Botswana. Focusing on these three examples will reveal how race was mobilised rhetorically (Buell 2005:38) in the creation of the nation. Through race variety, Ethnic Reasoning is able to bear on the making and construction of a harmonious nation. 
Race is highly contingent to Ethnic Reasoning. I propose that it is an ethnic category through which Botswana was able to create and imagine a peoplehood. Race is nothing but a historical invention and social construction. Buell asserts that the social construction of race means it can 'exist and have real significance in our lives because the societies in which we live organise and classify humans into 'races' and ethnicities (2005:6). Social construction depicts entities as neither fixed nor eternal but in perpetual influx, because 'changes in how races and ethnicities are defined over time indicate that they are in fact social creations and not eternal realities' (2005:6). Not only is race a social construction, it is also a political, religious, and historical invention, that functions as a marker of difference.

But what is race? Race, according to Pumla Dineo Gqola, is a 'way of seeing; ordering, experiencing the real racialised world' (2015:37). Gqola further contends that 'the history of race is the history of slavery, colonialism and race science' (2015:37). Race affects colonised lands and its people in varied ways. Through science, race was invented from 'an idea and elevated to a valid ordering and meaning-making system that relied on measuring the body of the enslaved and colonised' (2015:38). Therefore, discussing early Batswana contact zones with Europeans points to the way they perceived, viewed, ordered and experienced each other through the history and practice of colonialism, which was structured by race. The contact zones with Europeans would have social, political, and religious implications, as everything Batswana had built was undermined and destroyed through the European imperial and colonial practices.

Race not only emerges at the contact zones of Batswana, Asians, and Europeans before independence. In making itself as a nation, Botswana was aware of the production of race, and aware of race's power to reduced black people to their melanin (Frantz Fanon c1986: and Achille Mbembe 2017). It emerges through the apartheid system of South Africa because of Botswana's proximity to South Africa which forced the Botswana nation historically into the consciousness of race and racism and a thorn in the flesh of Botswana's nationalism. Therefore, this article cannot disentangle race from the making of a Botswana nation, for both political and socio-historical reasons.

Christian Makgala discusses the history of race relations between Batswana and the Europeans in his article, 'A Survey of Race Relations in Botswana, 1800-1966' (2004). Makgala asserts that initial contacts of Botswana and Europeans were historically traced to the 1800s. He traces the 
history of Batswana with Asians and Indians to the end of the nineteenth/early twentieth century (2004:11). The contact zones were not innocent contacts but overloaded with racial overtones. Makgala writes that Europeans held preconceived notions of Africans as unenlightened savages' (2004:11). Batswana's encounter with the Europeans transformed institutions of the 'socio-economic, religious and political systems of the Batswana' (2004:1112) Makgala states that the settling of missionaries is where the great racial consequences were harvested. The missionaries 'condemned their (Batswana) traditional customs and persuaded them to adopt Christianity and European customs' (2004:11).

Moreover, institutional and structural practices of race and racism ensued among colonial administrators and missionaries. Makgala notes that the British administration of the Bechuanaland Protectorate established a police force called 'Bechuanaland Protectorate Border Police (BPP) (2004:13). Its main objective was to 'solely protect the western border of the Transvaal against Boer intrusion into Bechuanaland' (2004:13f). Initially Africans were not recruited into the force but were only hired as 'wagon loaders and interpreters' (2004:13) whereas when whites invaded Bechuanaland, they came to hold only all important positions in the BBP. This practice of racial politics, racial prejudice and discrimination was the product of colonialism and race science which was prevailing in South Africa. Makgala asserts that 'so negative was their racial attitude towards Africans that the Basotho policemen were dismissed following allegations of incompetence for reasons of the economy' (2004:13). This would ultimately lead to the reconstitution of the Police in 1895 into 'two separate units, one for the Africans while the other was for Europeans' (2004:13). They were even labelled differently: Bechuanaland Mounted Police and Protectorate Native Police (2004). Therefore, racism operated in the Police force, but collapsed the objective of the Police force which was 'crime control' (2004:14).

Just before Botswana's independence, the Bechuanaland Protectorate underwent a serious tension over the Politics of race, and racialisation. In 1948, the heir apparent to the GaMmaNgwato's chieftaincy, and the grandson of Khama III, Seretse Khama, who would later become Botswana's first president, married Ruth Williams, an English white woman. The marriage, later dubbed the marriage of inconvenience, was unaccepted. Their marriage coincided with the zenith of the South African apartheid system and became a political offence and anomaly to the neighbouring South Africa's 


\section{Malebogo Kgalemang}

miscegenation laws. The miscegenation law is forced racial segregation and was a crime in racialised, raced, and apartheid contexts. It prohibited any sexual intimacies or marriages between blacks and whites. Apparently, Jeff Ramsay writes that Seretse and Ruth's 'marriage and its consequence sent Seretse's name ringing through the empire' (2002:135). Ruth and Seretse Khama were persecuted by the British government that was 'responding to pressures from the regimes of Southern Rhodesia and South Africa' (2002: 136).

Moreover, the colonial leaders of Southern Rhodesia and South Africa were recovering from their failure to incorporate the Protectorate into either. Both colonial territories' policies protested strongly against a mixed-race marriage. They were able to convince the British High Commissioner in Pretoria to ban Seretse from the territory. According to Ramsay (2002), the British government's decision to banish and exile the Khamas to England was in response to the "pressures from the racist regimes of Southern Rhodesia and South Africa. Because the British government was uncomfortable with South Africa's reaction to the mixed racial marriage, it began processes to banish Seretse and his wife from Southern Africa to England from 1949 until 1956 (2002:136). Parsons argues that 'the objection was to do with the political position of Seretse as an heir to a distinguished chieftaincy and the challenge of a mixed marriage posed to notions of racial, social, and political separation. This means realising the banishment was trickery' (1995:30). So, in 1950, Seretse was invited to England for a meeting. The meeting's objective was to discuss the "constitutional position of the marriage and the question of chieftaincy on the promise that he would be allowed to return to Bechuanaland to prepare his family for a life of exile in Britain' (1995:30).

Seretse Khama's uncle, guardian, and Bangwato regent, Tshekedi Khama was also opposed to his nephew's marriage to a white woman. Seretse Khama's marriage was not only an offence but he had violated the GaMmangwato marriage traditions and rituals. Tshekedi Khama was enraged and livid for he had not been consulted as it was customary for an uncle to be notified and take a leading role in the marriage negotiations. Second, for Tshekedi Khama, administration, tribal duty, and commitment were the more pressing matters of the protectorate. According to Ramsay, Tshekedi Khama, with the backing of the Commonwealth and Colonial Officer and various church leaders, succeeded in blocking their planned church wedding (2002:34). However, writes Ramsay, at a 'historic 25 June 1949 Kgotla 
meeting, which was well attended (136), Seretse Khama tendered an apology to the tribesman that he had not initially consulted them regarding his intention to marry, more so, to marry a white woman. He was forgiven and 'several thousand Bangwato overwhelmingly endorsed him and his marriage... which was well attended by the international press' (136). Seretse Khama would later reconcile with his uncle Tshekedi Khama. Race's apartheid materialisation in South Africa became a 'thorn in the flesh' of the making of the Botswana nation. Botswana therefore had no choice but to be opposed to the South African racial discourse and adopted 'the ideal of a non-racial democracy' (2002:136).

The flag of Botswana was one of the varieties Ethnic Reasoning used to adopt a resistance stance against South Africa's apartheid. The Botswana national flag consists of three colours: blue, black and white. The flag features its uniqueness. It is unlike the majority of the African nations' flags. Botswana's national flag lacks the Pan-African colours, red and green, which are found in the flags of many of African nations. The Pan-African red symbolizes the blood that was shared and unites people of Black African descent. And the Pan-African green represents the abundant natural wealth of Africa. Botswana's national flag's blue colour dominates the flag and symbolises colours for water, rain, and the vast Botswana blue sky often nestled with castle-like clouds. The blue flag has borders of black and white variants. Black represents the natives and white for people of European descent. Black and White colours symbolise the harmonious race relationships of the nation of Botswana.

The presence of black and white in the flag of Botswana 'shed light on the social contexts and power relations at work in the establishment and transformation of cultures and identities' (Buell 2005:37). The flag is a representation of the ethno-racial reasoning privileges of the Botswana race's self-description. This self-description echoes double rhetorical strategies. The black and white colours representation is meant to appeal rhetorically to racial harmony. On the other hand, it reflects the rejection, realities, and experiences of a nation, with the intention to ward off the hauntings of racial politics, or to rebut the negative history of race relations. Through the making of the nation of Botswana and the flag representation of race, Botswana is able to 'participate in this dynamic treatment of ethnicity/race' (Buell 2005:94). In essence, this was a decolonising move. Decolonisation is a subversion of racial ideologies that defined Southern African postcolonial politics. It disassembles 


\section{Malebogo Kgalemang}

constructions that perpetuate racial superiority and inferiority.

Buell asserts that 'ideas about race and ethnicity gain persuasive power by being subject to revision (flexible) while purporting to speak about fundamental essences (fixed) '(2005:94). The making of the Botswana nation used ethno-racial categories to reconstruct black-white relations andto imagine differences of race in harmony. Moreover, the use of Ethnic Reasoning in narratives as an ethno-racial is used to define and contest race and its racism as well to differentiate itself from its politics. On the other hand, with decolonising race and racism, Botswana did not discard the idea of race as a social and political identity of unity.

The marker of race is clearly fixed, for both countries depend on racial markers to attest and create politics of race and racism. However, Ethnic Reasoning in the making of the Botswana nation through the marker of race creates race as fluid. The fluidity of race signified by the flag's colours means that race and its racialising is not fixed permanently. Instead, Botswana's ethnic reasoning is able to define and contest 'race and discrimination' (Buell 2005:95) as well as to 'differentiate between them' (Buell 2005:95).

When Botswana focused on Ethnic Reasoning through the category race, it interpreted race for its own purposes. The Nationalism of Botswana appears in the ethnic reasoning of race, because of its history of racial encounters and effects. Though the category race reasoned ethnically through politics of racialisation and racism, Botswana in turn used race to 'manufacture national unity' (McLeod 2006:110). Through the category race, Botswana's ethnic reasoning sets the norms and limits how a nation imagines itself through a harmonious existence with different races (McLeod 2006:110).

Given that this section has focused on ethno-racial reasoning, the following section will explore how Botswana used ethnic reasoning through the categories 'tribe' and 'ethnicity' to construct and make the nation.

\section{Ethnic Reasoning and The Tribes}

Ethnic Reasoning allows a nation to 'not only describe (itself) as a people, but to also depict the process of becoming,' (Buell 2005:139). Ethnic Reasoning can be deployed to create a collective identity in which concepts of identities are used to draw out a distinctive notion of the nation (Buell 4). Collective identity is fundamental to nation building. It works through, according to 
Alberto Melucci, 'as a set of rituals, practices and cultural artefacts' (1995). This section will, therefore, attend to the forms or categories through which Botswana made the nation by appealing to existing discourses of nativity like The Tribes.

The use of the category The Tribes might be a misnomer for some scholars and readers because a number of (Batswana/ anthropological) scholars have since abandoned The Tribes. Most African countries abandoned the use of The Tribes for their nation states because The Tribes held colonial and imperial entanglements and were disavowed for tribalism and potential civil wars. This article cannot ignore The Tribes because in the ethnic context and culture of Botswana, The Tribes, their existences and traditional practices, are visible and held strongly. The Tribes remain foundational and form part of Botswana's cultural discourse. The Tribes have a persistent hold and are a stain in the psyche of the nation of Botswana and its constitution. Historically, the colonialists were instrumental to the recurrence of The Tribes.

In Ethnic Structure, Inequality and Governance of the Public Sector of Botswana (2004), Onalenna Selolwane, forsakes the use of The Tribes. Selolwane opts for Ethnicities and reads Botswana's construction through the category 'ethnicity and its values'. By replacing The Tribes with ethnicity or ethnic groups, Selolwane cements ethnicity as foundational. Ethnicity in Selolwane's work appeals to 'observable traits' like 'custom, belief, language...or putative common ancestry in the pursuit of a stable definition of ethnicity' (2004:130). According to Selolwane, Ethnicity in Botswana can be defined and located through language, ethnic geographical demarcations and ethnic dominance in public sector and governance in the public section of Botswana (2004).

Defining tribe and ethnicity is complicated and perhaps difficult to 'tame'. Definitions are not easily tamed. However, Sze-kar Wan argues that, 'there is no such thing as ethnicity. There is only ethnic construction' (2009:134). Whereas, Makgala provides cursory definitions of both tribe and ethnicity (2009). In fact, Makgala argues for a marriage between tribe and ethnicity (2009). Ethnicity, according to Makgala is 'simply cultural and linguistic identity while tribalism means the mobilisation and exploitation of ethnicity for political and economic gain' (2009:226). Makgala asserts tribe exploits ethnicity to create, construct, and mark the difference between (same) ethnic groups (2009:226). Tribe has connotations to imperial constructs and influence. 
Ethnicity is derived from the Greek word, ethnos. Its genealogy stems from classifying men, women, or the citizens of a polis (cities) in different groups. Ethnicity is unstable. It is often difficult to pin down because it embraces many aspects of a citizen's social, political, and perhaps religious life. The social or institutional categories like language, family, place (land) of origin, custom, and religion often form the five features that characterise ethnicities. Francis M. Deng asserts that ethnicity is more than skin colour or physical characteristics, and more than language, song and dance (1997). It is the embodiment of values, institutions, and patterns of behaviour, a composite whole representing a people's historical experiences, aspirations, and world view (Deng 1997).

The Tribes are doubly embodied in that they both are native and colonial. In his book, Define and Rule: Native as Political Identity (2012), Mahmood Mandami articulates a succinct observation of colonial and imperial alterations of the history of The Tribes. He questions firstly whether 'tribes existed (in Africa) before colonialism?' of which he says The Tribes existed 'if we understand by tribe, an ethnic group with a common language, it did' (2012:73). Furthermore, Mandami provides a colonial definition of tribe as an 'administrative entity that distinguished between natives and non-natives and systematically discriminated in favour of the former against the latter' (2012:73). From the imperial weaving of The Tribes, colonial administrators constructed policies and drew local tribal maps that came to define 'access to land and participation in local governance and rules for settling disputes' (2011:73-74). These, as Mamdani mentioned, were practices after the onset of colonial and imperial restructuring of native lands (2012:23f).

Edwin S. Segal has argued that 'the existence of tribes is the defining characteristic of the continent's people' (2000:6). Segal further says that 'while we think identification is a real micro-cultural ephemeron, on the national level it is reshaped into tribalism in a variety of ways' (2000:6) Tribalism is 'ethnicity played out on a national scale, an assertion that local level cultural differences are permanent, competitive, and the source of national inequalities' (2000:6). Ethnic reasoning, therefore, through The Tribes offers an 'analytic point of entry' (2000:60 into nativist nationalism. Charisma defines nativist nationalism as 'politics whose authority rests primarily upon the claims of, and to, 'native' cultural identity or ethnicity' (2004:192).

Historians and linguists locate Botswana's appeal to The Tribes to 1933 when the British authorities recognised and authorised 'eight tribes in the 
Chieftainship Act as follows: the Barolong, Bakwena, Bangwaketse, Balete, Bakgatla, Batlokwa, Bangwato and Batawana' (Nyati-Ramahobo 2008:5). Geographically six of the tribes make their stable locations in the south, and two in the north or central district. According to a document by Reteng cultural group, the eight Tribes spoke the same language and shared main features in their culture with differences in some respects (2008:5). The British Empire colonial government protectorate 'drew eight internal colonial boundaries, dividing the whole Protectorate into tribal territories' (2008:5). They relied deeply on the tribal demarcations by the tribal authorities and chiefs. These tribal demarcations came to have a bearing historically on how the nation perceived, viewed, and imagined itself. The tribal act had divided the country according to the dominating tribe of the land and the land according to the ethnicity and language of the initial three: Bangwato, Bakwena and Bangwaketse,who were seen as strong tribes to 'dominate subject peoples on behalf of the colonial power' (2008:8). The colonial administration would later include the 'subordinate sovereigns' (2008:8) who were the military powerless, Balete, Bakgatla, Batawana, Barolong and Batlokwa (2008). Through their language and history, they created the major tribes of Botswana. Selolwane details that the eight major tribes, who are mainly Setswana speakers have 'historically named their language and themselves after the various particular individual polities they belonged to' (2004:9). Whereas, Nyati-Ramahobo underscores that the 'eight major tribes speak dialects which are mutually intelligible and collectively known as the Setswana language' (2008:5). For example, Bangwaketse, Bangwato and Bakwena may perhaps have come from one large Setswana ethnic group. If the Bangwato and Bakwena seceded from Bangwaketse, their identity came to be based on the name of their founder or leader who led the secession (Selolwane 2004:9) or possibly trace their genealogy to one related, possibly patriarchy.

Parsons writes that the British founded the nation of Botswana or the colonial state of Bechuanaland on Tswanadom, and which subsequently became the foundation of the modern and sovereign state of Botswana (2005). Parsons asserts that Tswanadom was possible with the cooperation of the Tswana male leaders of the time (2005). Tswanadom signifies a Tswana cultural and political dominance in public life. This Tswanadom was 'both philosophical and territorial' (Parsons 2005). According to Parsons, it 'led many observers to assume that Botswana is a mono-ethnic state... but only in so far as the Tswana minority has successfully imposed its culture on the 


\section{Malebogo Kgalemang}

majority population of the extreme diverse' (2008:9). Nyati-Ramahobo extends Parsons' argument when she notes that Botswana law permits 'discrimination on the basis of ethnicity, language and culture' (2008:9). NyatiRamahobo contends that the goal at independence was to assimilate all ethnic groups in the Tswana culture and create a monolithic state, a model found in most British colonies. Botswana has held on to the colonial construction of Tswanadom' (2008:9).

The nation of Botswana was partly founded on minor and major tribes. The latter were formed of eight principal tribes while the rest became the minor tribes. The eight major tribes found their way into the Botswana constitution under the now defunct Sections 77, 78, and 79. The eight major tribes came to take over the nation and against the minor tribes. The minor tribes included Bakalanga, Basarwa, Bakgalagadi, Basubiya, Wayeyi, Bambukushu, and Baherero. They were and are characterised by non-Setswana native languages and with no recognised or paramount chiefs. However, the major tribes each had a paramount chief, who, according to section 77,78 , and 79 was ex-officio of the House of Chiefs.

Sections 77, 78, and 79, sanctioned the creation and legitimisation of the eight major tribes and minor tribes. Acts and assertions of the major tribes' superiority were made through the constitution's section 77,78 , and 79 . Since 77,78 , and 79 worked through a binary couplet of major and minor, it was found to be discriminatory and exclusionary. There had been motion calls to the government to repeal these sections. Some made by members of a Parliament.

Voices of dissent emerged from the tribe Bayei who initially sought their own representatives in the Ntlo ya Dikgosi. The then President Mogae initiated a review of sections 77-79 of the constitution. President Mogae gave the commission three tasks which were the following: To review sections 77 , 78 , and 79 and seek a reconstruction that would eliminate any interpretation that renders the sections discriminatory. Second, to review and propose the most effective method of selecting members of the 'Ntlo ya Dikgosi' House of Chiefs, and third, to propose and recommend measures to enhance the efficiency and effectiveness of the House of Chiefs' (Ndolamo Morima 2020). These terms of reference addressed discrimination, exclusion and marginalisation deployed and institutionalised through tribal discrimination.

Nyati-Ramahobo asserts that the 'minority' and 'majority' indicate a 'numbers definition, meaning the few (the minority) and the many (the 
majority)' (2002:689). She says it functions both in everyday life but pertinent also 'for state-backed official use' (2002:689) that forms the 'distinction between the powerless and the powerful, without reference to the numbers' (2002:689). She argues that the making of the 'minority' and 'majority' is 'grounded in Tswanadom, originally backed by the colonial state under the British and now sustained by the postcolonial state' (2002:689). According to Latang Sechele, minority tribes are groups of people with non-Tswana background who either were brought voluntarily or by compulsion into the orbit of Tswana chiefdoms. They experienced discrimination and marginalization (2019). The minor and major tribes are a binary couplet functioning to make the nation of Botswana. However, there simply are no minor and major tribes but deliberate powerful constructions that have sustained the imagination of the Botswana nation. The 'major' Tribes' ethnic reasoning is an appeal to one large ethnic group, composed of about eight tribes, bound by one common language that is essentially ...? but all a construction that partly emerges as a local practice of imperialisation in which tribalism was created.

Ethnic Reasoning created the nation of Botswana through the ideology of Tswanadom particularly with the dominance of the homogeneity of the major Tribes. Their distinctions are mythologised through 'unique' cultural and minor language differences. Through Ethnic Reasoning, the making of the Botswana nation erased, or ignored and pushed to the periphery any possibility of heterogeneity. The homogeneity of Tswanadom became the overarching drive towards the imagination of the Botswana nation. Parsons is on point when he contends that Botswana's nationhood was an 'assimilationist model for the socio-cultural development of its people' (2005:17). This assimilationist model wrote the ideology of Botswana's homogeneity through major tribes' Ethnic Reasoning. Tswanadom continued colonial and imperial sentiments of domination and came to colonise the rest of the non-Tswana tribes. It led to a monolithic ideological construct that 'assumes Botswana is a mono-ethnic state' (Ramahobo 2008). This imperialism works through creation and demand of inside (tribes) and outside (tribes), of centre and margin, which use the power construction of eight major tribes in the centre and minor tribes on the periphery to affirm the nation of Botswana.

One of the dynamic characters of Ethnic Reasoning, according to Buell (2005), is the idea of fixity signalling permanence and eternity. This fixity is ascribed along geographical demarcation and language domination. The major 


\section{Malebogo Kgalemang}

Tribes in the making of the Botswana nation purported an ongoing, if not perpetual eternal practice of remaining fixed through the Setswana language. This perpetual language practice was utilised in the making of the nation. The Setswana language spoken has come to define the ethno-tribe reasoning of the nation as fixed. The making of Botswana thus appeals to the discriminating combination of existing tribal/ethnic practices and interpretations.

The Setswana tribes/ethnicities that made and defined the nation through language and assimilated other groups do not hold any 'specified content at all times (the primordalist view) but perhaps carry a self-serving tool constructed in the service of political gain (instrumentalist view)' (Buell 2005:40). Given the making of the nation of Botswana through traditional and colonialist construction of The Tribes/Ethnicities, the making of the nation seems to have juxtaposed 'the dynamic character of ethnicity or tribe as being both fixed and fluid' (2005:140) The state's name, Botswana, and its people Batswana, all derive from The Major Tribes' homogenous creation through language. The citizens of the nation of Botswana are Batswana. Every citizen is a Motswana whether they belong to either a minor or major tribe. One is construed a Motswana whether born a mosarwa, a mokalaka or mongwato. Through the terms 'Botswana' and 'Motswana', Botswana's ethnic reasoning is able, through fixity and fluidity, to create universalising claims of the nation of Botswana. The Tswanadom universalism carries the making of the Botswana nation and its self-understanding of a peoplehood through the fixed major Tribes. Therefore, Botswana, Batswana, Setswana or Motswana are all fixed through The Major Tribes.

The making of the nation through The Tribes/Ethnicities gives the nation its fixity/fluidity. Rather the Universalism (or assimilation of minor tribes into the Botswana nation) of Tswanadom allows anyone to become a Motswana which renders Tswanadom fluid. Any person belonging to a minor tribe, and not 'swallowed' into The Major Tribes is a Motswana, a construction finding its origins in The Major Tribes. They are, in fact, assimilated into the imagination, into the idea and the construction of Botswana, made possible by the imagined nation of Botswana.

The ethnicity of Motswana is fundamental to the making of the nation, and deriving its meaning from The Major Tribes, makes Motswana doubly embodied, as it is both tribalised and ethicised. A non-Motswana (or a foreigner) cannot become part of The Tribes since The Tribes are fixed and essentialised through language, lineage, or constructed values and belief 
systems. However, a foreigner or expatriate can become a Motswana as long he meets certain ethnic reasoning values and requirements of the state of Botswana. This entrance into the Botswana nation reveals the fluidity of the nation's ethnicity which is highly contingent to the making of the nation. The fluidity of ethnicity signifies being porous, open, and accessible. Through the fluidity of ethnicity, Botswana citizenry becomes open and accessible to all. In other words, anyone can become and is a Motswana through the 'mutability of ethnicity' (Kimber Buell 2005).

The 'mutability of ethnicity is real and enables universalising claims (Buell 2005:40). These claims are that all the constructed major and minor tribes are Batswana by virtue of their native and tribe statuses if not language. On the other hand, through the fluidity of ethnicity, Botswana citizenry becomes open to all. However, 'fixed/fluid dynamics of ethnic reasoning functions to reveal and conceal the fuzziness of the boundaries' (2005:40) between the minor and major tribes. The Borders, though made through language and lineage of the minor and major, are on the other hand eliminated through the universalising claims of nationhood and nationalism. Furthermore, the fixity of The Tribes/Ethnicities of minor and major tribes is won and sustained through the fluidity of ethnicity which is maintained through language. Through part ethnic reasoning's use of The Tribes, Botswana is able to self-define and construe itself universally as a peoplehood.

Botswana's dependency on the ideology of The Tribes to create and imagine the nation, makes The Tribes an important category of the nation of Botswana's Ethnic Reasoning. The construction of eight major tribes became a powerful mechanism for members of the major tribes and for the making of the nation.

Language, as already pointed out, is fundamental to the fixed/fluidity dynamic. The nation of Botswana is defined and made through two recognised languages: Setswana and English. The former is a national language, and the latter official. Below I explore the role of language as a carrier of culture and as a marker of a peoplehood of the nation of Botswana.

\section{The Making of the Nation through Ethno-Language}

The category language is the embodiment of a culture and a form of cultural identity. The category language is used to create a national collective identity through the practice and performance of language(s). People use language to 


\section{Malebogo Kgalemang}

transmit its culture and socialise its members. However, with Botswana's multi-lingual culture, two languages, Setswana and English have been centred categories of Botswana's Ethnic Reasoning. Theophilus Mooko asserts that like many countries, Botswana adopted the language of its former colonial ruler, Britain, as official language' (2009:19). He says Setswana, one among many of the indigenous languages 'has been accorded the status of national language' (2009:19). A national language signifies the language used for national identity. It is often the 'symbol of national identity and a mobilisation and rallying point. Every bonafide language is emblematic of the spirit of a nation and is seen as a unifying force' (Obeng \& Adegbija 2004:363).

Therefore, the formulation of the Botswana nation was formed partly and ethnically through the practice of Setswana, in addition to the English language. However, the Setswana language over and above the coloniser's language, enabled the emergence, unification, and consolidation of the nation of Botswana. As a national language, Setswana became an exclusive language against many different languages spoken in Botswana. Setswana also came to colonise non-Tswana speakers, thus creating a homogeneity of a language for a peoplehood. In their delineation of Botswana languages, the writers of the Sheyeyi document, Reteng, assert that 'the idea of a nation has been legitimised throughout history partly on the basis of its citizens sharing a common language' (2008).

Every language, according to Samuel Gyasi Obeng and Efurisibina Adegbija, 'carries a distinct and weighting ethnic baggage' (2003:353). It is seen as the 'storehouse of ethnicity in which ethnic groups 'express and identify' with the language they speak, and its cultural paraphernalia, shaped by its language' (353). Reteng's Cultural Group's compilation writes the following regarding the privilege and centrality of the Setswana language, 'tswana speaking public officers such as nurses, teachers, and the police were posted to non-Tswana villages and were expected not to learn the local languages but to use Setswana only and apply Setswana customs as the standard norms' (2008). In some non-Tswana villages, Batswana teachers who were not familiar with, for example, Kalanga orthography compelled Kalanga children to ask their parents to change their Kalanga names to Setswana or English, since the teachers were unable to transcribe non-Tswana names.

However, Botswana has many other languages apart from the two noted above. According to Nyati-Ramahobo (2008), there are about 10 other languages. Some linguists suggest Botswana can be grouped into nine fairly 
discernible classes of Bantu languages and ten or more Khoisan languages and one Indo-European group (see Selolwane 2004:6). These ten languages are considered the languages of the minority as they are only spoken by the socalled minor tribes. They are neither written nor recorded, and they do not find a space of expression in both the state and private media, except Setswana and English. The ten languages of the so-called minority tribes have been denied a space and a seat in the process of the making of the Botswana nation. Shekgalari, Sheyeyi or Kalanga are either studied by linguists or the Bible will be translated into these.

Ethnic Reasoning through the domination of the Setswana language and in the making of the nation of Botswana produced the death of other languages. Moreover, through the domination of the Setswana languages, the non-Setswana languages are othered continually. Othering is a postcolonial theory category introduced by Gayatri Chakravorty Spivak (1999). Spivak asserts that colonialists constructed discursive and material outputs which were used to order, represent, and create the natives as other (1999). I propose that the privilege of the Setswana language be worked through the othering of nonSetswana languages. Since the non-Setswana languages are languages of the minor tribes, they were represented as inferior. Though non-Setswana languages are spoken in Botswana, the Setswana speakers are denied from learning and speaking the non-Setswana languages. Second, non-Setswana languages are further othered when they are not publicly transcribed or produced in literary output and orthography. The non-Setswana languages are kept in the periphery of both the national and official languages. The national language, therefore, produces ethno-tribal languages historically.

What then are the other forms of the making of the nation of Botswana's ethnic reasoning through the variety of ethno-tribal languages? The exclusive privilege and use of Setswana language as a national language, where every citizen is expected to speak Setswana in public and official spaces, uses the Setswana language polemically. The polemic of Setswana 'authorises its own visions' (Buell 2005:134) of Botswana. The visions of Botswana through the official language both exclude and include tribes and ethnicities that speak Setswana through Botswana's nationalist imposition. Setswana is, moreover, a language performance of ethnic reasoning.

The polemic of Botswana's ethno-national reasoning raises a number of rhetorical strategies. Firstly, its agenda is to promote and privilege one indigenous language, create language inequality, and deny language rights - 


\section{Malebogo Kgalemang}

which is a practice of ethno-national reasoning. It denies, as Mooko (2009) demonstrates, non-Setswana languages and its peoples, the space and infrastructure to create knowledge. It denies non-Setswana speakers' resources to create and produce linguistic output similar to the national language's function. Furthermore, it denies the utilisation of non-Setswana languages to participate fully in the political and socio-economic domains. Another polemic of Botswana's ethno-national reasoning is its failure to promote multilingualism. For example, the effort to allow community radio stations as part of ethno-national building has always been seen as a potential to tribal tensions.

Botswana's ethno-national reasoning creates and constructs 'universalising claims' (Buell 2005:97f) about the nation of Botswana through the privilege of Setswana as a national language. To universalise is to encapsulate entities into a unity without paying attention to differences. Universalising claims means creating a homogeneity, or a single unit of practice or truth. In the making of the nation, Botswana's universalism through Setswana languages was important for the nation's unity and peoplehood.

Setswana language unites the nation of Botswana into becoming and constituting a unity and a peoplehood. However, the universalising claims of the making of the nation into one, begin from the particularity of ethno-tribe, thus emphasising the tension of the particular/universal forms of nation making. Initially, Setswana is a language particular to the eight major tribes. Its imposition into a national language makes Setswana straddle the particular and the universal, thus making it both fixed and fluid. However, as a national (and universal) language, Setswana is produced and emphasised in the following: every native/indigenous person of Botswana is a Motswana; every Motswana should speak Setswana. This ethno-national reasoning claims to build and consolidate a nation with one language, one culture, and one flag, that colonises the natives into one shared culture, and social and political identity.

According to Anderson (2006), the existence of a community or nation is often imagined through language. Anderson argues the following regarding the function of language for imagining the nation,

It is always a mistake to treat language in the way that certain nationalist ideologies treat them as emblems of nation-ness, like flag costumes, folk-dance, and the rest. Much of the most important thing 
about language is its capacity for generating imagined communities, building in effect particular solidarity (c2006:133).

Anderson points out rightly that language functions to 'generate imagined communities', for it has the capability for 'building in effect particular solidarity' (2006:122). The ethno-national reasoning and value of the Setswana language is captured succinctly often in newspapers and public writings. Below is advocacy for imagining the nation through the Setswana language from the lexicographer, Thapelo Otlogetswe (2016). He claims the following about the Setswana language.

Setswana must be declared Botswana's official language for Botswana to be a nation; for Batswana to feel patriotic. For full national unity to occur Batswana must not only be united by a flag and a national anthem, they must be united by a common language and culture. As long as Setswana is not Botswana's official language there will forever be a sense of alienation amongst the citizens. There will be cultural and linguistic erosion. This will lead to disconnect between the citizens and their country, which will engender national insecurity. There will be nothing unique about being a Motswana. We as a people of Botswana have lost a sense of national dress that sets us apart. We are increasingly losing pride in our diet and cuisine. Every day our culture is being eroded with our assistance and participation. Our language is on the line. Shall we sit by and watch helplessly as it fades away? Shall we be the generation that failed to transfer its language to its children? (2016).

Otlogetswe makes a compelling call for Setswana to transform from the national language to an official one with 'Setswana must be declared Botswana's official language' (2016). When he calls for Setswana to be declared an official language, Otlogetswe (2016) does not state the differences between an official and national language. According to Noriko Iwamoto, 'a national language has more symbolic characteristics as an emblem of a community than an official language, which is used for practical purposes for communicating at national level' (2005:101). However, Otlogetswe (2016) insists Setswana can function better with an official status.

Otlogetswe (2016) bases his call for Setswana's official language 


\section{Malebogo Kgalemang}

status on a number of categories of ethno-national reasoning. Otlogetswe (2016) claims there are repercussions to Setswana's unofficial status. He argues that Batswana will 'forever feel a sense of alienation' (2016), that they will experience 'cultural and linguistic erosion' (2016), and there will be a 'disconnect between the citizens and their country which will endanger national insecurity' (2016). According to Otlogetswe (2016), making Setswana official will enable Botswana to feel patriotic and a Setswana uniqueness will not be lost.

Otlogetswe's (2016) claims a call for Setswana to be official is neither new nor strange. It is in the similar trajectory of those who came before him; the founders who privileged and universalised Setswana as the language of Botswana's nation making. This type of call is ethnic reasoning drenched in ethnocentric claims. Otlogetswe (2016) views Setswana as a carrier of a unique Botswana identity which partly forms a prerequisite to patriotism and nationhood. He privileges, marks and foregrounds Setswana with an unsurpassed monolithic logic into the making of a Botswana nation. Botswana's best unique collective and distinctive identity is perceived with 'as long as Setswana is not Botswana's official language there will forever be a sense of alienation among citizens' (2016).

In Citizenry and Subject: Contemporary Africa and the Legacy of Colonialism (1996), Mahmood Mamdani's observation about Africa and its perspective is poignant. Mamdani says 'the impasse in Africa is not only at the level of practical politics. It is also a paralysis of perspective' (1996). Invoking Setswana as an exclusive marker and construction of a true Botswana identity has the potentiality of a 'paralysis of perspective' (1996). Foregrounding Botswana identity as the 'real, material and lived' (1996) through a common language and culture, and 'materially through a national dress' (1996) inputs basic fundamentals to the heterogeneity of the nation. Otlogetswe's (2016) imagined category of Setswana's official statues at the expense of other languages (minor) reproduces and inputs an essentialised notion of the nation. In fact, foregrounding Setswana at the centre of Botswana nation and its nationalism implies the core of ethnic reasoning. When Otlogetswe draws and establishes Setswana as a category of social and national cohesion he creates an ideology of Setswananess privilege, simultaneously constructing nonTswana ethnic speakers through an exclusive Setswananess. Otlogetswe (2016) seeks all The Tribes/Ethnic groups (or tribes) to be fixed with a Setswana understanding and conceptualisation. Setswana will mark Batswana 
consistently with unity and a single understanding of their Nationhood. Therefore, Otlogetswe (2016) uses Setswana as an ethnic reasoning fluidly to articulate and advocate towards a fixity of Tswanadom. Simultaneously, Otlogetswe's use of Setswana language 'stabilises this fluidity by appearing to speak about a coherent, distinct group' (2005:97): the real Botswana: a new nation, resisting forms of loss of Setswana language.

\section{Conclusion}

The goal of my study was to explore through Buell's Ethnic Reasoning the making of Botswana's nationalism. This paper traced and explored various categories and varieties instrumental in the making of the Botswana nationalism. I discussed ethnic reasoning categories of Race, The Tribes and Ethnicity and lastly language particularly the privilege of Setswana language as national language. This paper strategically chose also not to make distinctions between The Tribes and Ethnicity even though both are differently defined because Botswana continues to cling to The Tribes.

This article laid a claim of the universal and the particular and how the connection between the two are implicated in the imperial assertion and dominance of Botswana's ethnic reasoning of the nation through Setswana language. Rewriting and rethinking Botswana Nation's universalising claims gives us an opportunity to reflect on the 'effects of interpretive framework' (Buell 2005:165) that have construed Botswana's efforts at self-definition in sharp contrast?. Botswana, like any other nation, is invested in the power of nationalism and cannot abandon universalising claims.

Through Said, this article stated, 'Nations are narrations' (1994: xiii) through ethnic reasoning. It not only negotiates and constructs collective identities in an ever changing socio-political and cultural context. It is established continually, envisioned and asserted as already demonstrated. The imagined Botswana nation has remained consistent. Its consistency is the persistent and stubborn assertion of the Setswana language as the continued precursor of the imagined Botswana nation. Its consistency is also perceived in the repression of Ethnic Reasoning's salient narratives in preference to an ethnic reasoning hegemony. Furthermore, Ethnic Reasoning demonstrates how Nationhood, through the intersectional and interlocking categories of the privileging of the Setswana language, the eight major and minor tribes, and recognition of two races, was articulated and contested. Through the idea of a 
Motswana universal claims, there seems to be an insistence on an almost single understanding of Botswana nation. In the end, political process and practices of decolonisation are forever in the horizon and will not realise fully their horizons in the mind's eye (Bhabha 1990:1).

\section{References}

Anderson, B. c 2006. Imagined Communities: Reflection on the Origin and Spread of Nationalism. London; New York: Verso.

Bhabha, H. 1990. Introduction. In Bhabha, H. (ed.), Nation and Narration. London: Routledge.

Chakrabarty, D. 1999. Nation and Imagination: The Training of the Eye in Bengali Modernity. Topoi 18: 29 - 47.

Charisma, L. 2004. Nationalism and Postcolonial Studies. Lazarus, N (ed.):

The Cambridge Companion to Postcolonial Literary Studies. New York:

Cambridge University Press.

Deng, F. 1997. Ethnicity: An African Predicament. The Brookings Review 15, 3, Summer.

Henderson, W. 1990) 'Seretse Khama: A Personal Appreciation. African Affairs 89, 354, January.

Hyam, R. 1986. The Political Consequences of Seretse Khama: Britain, the

Bangwato and South Africa 1948 - 1952. The Historical Journal 29, 4,

December.

Iwamoto, N. 2005. The Role of Language in Advancing Nationalism. Bulleting of the Institute of Humanities 38.

Kamanakao, I. \& Others v. THE ATTORNEY GENERAL and Another 2001

(2) BLR 654 (HC).

Kimber Buell, D. 2005. Why This New Race: Ethnic Reasoning in Early

Christianity. New York: Columbia University Press.

Lentz, C. 1995. 'Tribalism' and Ethnicity in Africa: A Review of Four Decades of Anglophone Research. Cah. Sci. Hum 31, 12.

Makgala, C.J. 2004. A Survey of Race Relation in Botswana, $1800-1966$. Botswana Notes and Records 36: 11 - 26.

Makgala, C.J. 2009. History and Perceptions of Regionalism in Botswana, 1891 - 2005. Journal of Contemporary African Studies 27,2: 225 - 242.

Mamdani, M. 1996. Citizen and Subject: Contemporary Africa and the Legacy of Late Colonialism. Princeton, New Jersey: Princeton University Press. 
Mamdani, M. 2012. Define and Rule: Native as Political Identity. Cambridge, Massachusetts; London, England: Harvard University Press.

Mbembe, A. 2017. Critique of Black Reason. Johannesburg: Wits University Press.

McClintock, A. 1996. Imperial Leather: Race, Gender and Sexuality in the Colonial Contest. New York: Routledge.

McLeod, J. 2000. Beginning Postcolonialism. Manchester: Manchester University Press.

Mogalakwe, M. 2006. How Britain Underdeveloped Bechuanaland Protectorate: A Brief Critique of the Political Economy of Colonial Botswana. Africa Development XXXI, 1: 66 - 88.

Mooko, T. 2009. 'Language Policy and Practice in Botswana in the Context of Education for Sustainable Development. Language Matters 40, 1: 18 - 34. Morima, A.N. 2020. Botswana's Tribal Equality: 20 Years after the Balopi Commission and Kamanakao Case. The Weekend Post Newspaper. (Accessed in June 2020.)

Nyati-Ramahobo, L. 2009. Minority Tribes in Botswana: The Politics of Recognition. London: Minority Rights Group International.

Nyati-Ramahobo, L. 2002. From a Phone Call to the High Court: Wayeyi

Visibility and the Kamanakao: Association's Campaign for Linguistic and

Cultural Rights in Botswana. Journal of Southern African Studies

December, 28, 4, Special Issue: Minorities and Citizenship in Botswana.

Oakes, P. 2006. Why this New Race? Ethnic Reasoning in Early Christianity

by D.K. Buell. The Classical Review 56, 2, October: 500 - 502.

Otlogetswe, T. 2016. Why Setswana must be made Botswana Official Language. 'The Linguistic Chair', Sunday Standard Newspaper Column.

Parsons, N. 1971. Colonial Rule and Local Response in the $19^{\text {th }}$ and $20^{\text {th }}$ Centuries. Botswana Notes and Records.

Parsons, N. 1971. The 'Image' of Khama the Great - 1868 to 1970. Botswana Notes and Records 3: 40 - 58.

Ramsay, J. 2002. Ruth Khama: A Life of Service. Botswana Notes and Records 34.

Reteng: The Multicultural Coalition of Botswana 2007. Alternative Report Submitted to the Human Rights Committee on the International Covenant on Civil and Political Rights.

Said, E. 1993. Culture and Imperialism. London: Chatto \& Windus.

Sechele, L. 2019. The Marginalisation of Minority Ethnic Groups in Botswana: 
A Call for a More Inclusive Society. Paper presented at the International Conference: Race, Identity, and Globalisation in Southern Africa and Beyond, University of Botswana, 22 - 23 February 2019, Gaborone, Botswana.

Segal, E.S. 2000. Intersections among Tribalism, Ethnicity and Gender in the Light of African Data. Sociological Bulletin 49, 1: 1 - 17.

Selolwane, O. 2004. Ethnic Structure, Inequality and Governance of the Public Sector of Botswana.

http://unpan1.un.org/intradoc/groups/public/documents/undpadm/unpan040303.pdf

Spivak, G.C. 1999. A Critique of Postcolonial Reason: Toward a History of Vanishing Present. Cambridge, Massachusetts: Harvard University Press. Sze-ker, W. 2009. To the Jew and also the Greek: Reading Romans as Economic Construction. In Laura Nasrallah and Elizabeth Schussler Fiorenza (eds.): Prejudice and Christian Beginnings: Investigating Race, Gender, and Ethnicity in Early Christian Studies. Minneapolis: Fortress Press.

Shivji, I.G. 2003. The Rise, The Fall, and The Insurrection of Nationalism in Africa. Paper from Keynote Address to the CODESRIA East African Regional Conference held in Addis Ababa, Ethiopia, October 29-31. Wilmsen, E.N. 2002. Mutable Identities: Moving beyond Ethnicity in Botswana. Journal of Southern African Studies 29, 4.

Zolber, A.R. 1973. Tribalism through Corrective Lenses. Foreign Affairs 51, 4.

Malebogo Kgalemang Senior Lecturer Department of Theology and Religious Studies University of Botswana Gaborone kgalemang@ub.ac.bw 